\title{
The Phosphodiesterase Type 4 Inhibitor, Rolipram, Enhances Glucocorticoid Receptor Function
}

\author{
Andrew H. Miller, M.D., Gerald J. Vogt, Ph.D., and Bradley D. Pearce, Ph.D.
}

Previous studies have demonstrated that antidepressants can enhance glucocorticoid receptor (GR) translocation and function, possibly through activation of cAMP and downstream cAMP dependent protein kinases. Accordingly, we examined GR function in cells treated with rolipram, a phosphodiesterase (PDE) type 4 inhibitor that antagonizes cAMP breakdown. Compared with vehicle-treated cells, rolipram alone and in combination with dexamethasone significantly enhanced GR function as measured in both mouse L929 cells and rat C6 glioma cells stably transfected with reporter genes driven by upstream glucocorticoid response elements. Rolipram's facilitation of $G R$ function was reversible by the GR antagonist, RU486, and was associated with reduced cytosloic $G R$ binding, indicating rolipram enhancement of $G R$ nuclear translocation. Finally, rolipram potently augmented GR enhancement by the antidepressant, desipramine. These findings broaden the potential pathways by which PDE type 4 inhibitors can influence cellular function and indicate that these agents may have special utility in disorders associated with impaired GR-mediated feedback inhibition.

[Neuropsychopharmacology 27:939-948, 2002]

(C) 2002 American College of Neuropsychopharmacology.

Published by Elsevier Science Inc.
KEY WORDS: cAMP; Mood disorders; Depression;

Autoimmune disorders; Tumor necrosis factor alpha; Hypothalamic-pituitary-adrenal axis; Antidepressants; Multiple drug resistance pump

Hyperactivity of the hypothalamic-pituitary adrenal (HPA) axis is a common and reproducible finding in patients with major depression (Pariante and Miller 2001; Holsboer 2000). A major factor responsible for these HPA axis changes is believed to be increased cor-

From the Department of Psychiatry and Behavioral Sciences, Emory University School of Medicine, 1639 Pierce Dr., Suite 4000, Atlanta, GA 30322.

Address correspondence to: Andrew H. Miller, M.D., Department of Psychiatry and Behavioral Sciences, Emory University School of Medicine, 1639 Pierce Dr., Suite 4000, Atlanta, GA 30322. Tel.: (404) 727-8260; Fax: (404) 727-3233; E-mail: amill02@emory.edu 2002.

Received January 9, 2002; revised May 23, 2002; accepted May 29,

Online publication: 5/30/02 at www.acnp.org/citations/ Npp053002314/default.htm. ticotropin releasing hormone $(\mathrm{CRH})$, which may also contribute to the behavioral features of this disorder (Owens and Nemeroff 1993). Altered feedback regulation of CRH by glucocorticoids is one mechanism that may contribute to the CRH changes found in major depression (Pariante and Miller 2001; Holsboer 2000). Specifically, evidence exists that the receptors for glucocorticoids may become impaired in major depression, leading to glucocorticoid resistance in selected body tissues including the brain and immune system (Pariante and Miller 2001; Holsboer 2000). Recent evidence suggests that antidepressants may reverse glucocorticoid receptor changes in depression by direct effects on the glucocorticoid receptor (GR) (Pariante and Miller 2001; Holsboer 2000; Holsboer and Barden 1996). Both in vitro and in vivo data indicate that antidepressants can increase GR number and facilitate GR function (Pariante and Miller 2001; Holsboer and Barden 1996). Given evidence that a number of antidepressants have effects on signal transduction pathways involving cyclic AMP 
(cAMP) (Chen and Rasenick 1995a,b; Nestler et al. 1989; Nibuya et al. 1996), there has been speculation that the influence of antidepressants on GR is through their effects on cAMP-related signal transduction events (Pariante and Miller 2001).

A large body of data demonstrates that cAMP signal transduction pathways are involved in the regulation of the GR. For example, direct evidence of facilitation of GR function has been demonstrated for $\beta 2$ receptor agonists, cAMP, and protein kinase A (PKA) (Eickelberg et al. 1999; Schmidt et al. 2001; Sato et al. 1996; Rangarajan et al. 1992). Phosphodiesterases (PDE) are a group of enzymes that catalyze the breakdown of cyclic nucleotides (Beavo et al. 1994). The PDE isozyme type 4 is specific for cAMP and is expressed throughout the brain and immune system (Perez-Torres et al. 2000; Engels et al. 1994). Thus, inhibitors of PDE type 4 provide a pharmacologic strategy to increase prevailing cAMP levels in relevant target tissues.

One PDE type 4 inhibitor, rolipram, has been shown to have antidepressant effects (Zhu et al. 2001; Bobon et al. 1988, Eckmann et al. 1988). Rolipram was first demonstrated to have potent antidepressant activity in animal models (Zhu et al. 2001; Wachtel and Schneider 1986). However, clinical trials, while providing evidence of efficacy, revealed gastrointestinal side effects (nausea) and lack of clear superiority over other agents (Zhu et al. 2001; Eckmann et al. 1988). Interestingly, rolipram also has been found to exhibit potent anti-inflammatory properties including inhibition of the pro-inflammatory cytokine, tumor necrosis factor (TNF) $\alpha$ (Zhu et al. 2001; Ross et al. 1997). Since many of rolipram's immunologic effects appear to be consistent with the actions of glucocorticoids, and we have posited that antidepressants work in part through their effects on GR function, we wondered whether rolipram may have direct effects on the GR. Using cell lines stably transfected with reporter gene constructs downstream of a mouse mammary tumor virus (MMTV) promoter containing multiple glucocorticoid response elements (GREs), the present study endeavored to address the impact of rolipram on GR function.

\section{MATERIALS AND METHODS}

\section{Materials}

Rolipram, unlabeled dexamethasone (Dex), desipramine hydrochloride (DMI) and RU486 were obtained from Sigma (St. Louis, MO). Radiolabeled $\left[6,7^{3} \mathrm{H}\right]$ Dex was obtained from New England Nuclear Research Products (Boston, MA). The LMCAT cell line was generously provided by Dr. E.R. Sanchez (Department of Pharmacology, Medical College of Ohio, Toledo, $\mathrm{OH}$ ). The pMAMneo-LUC luciferase expression vector was a kind gift from Dr. D. Miller and Dr. P. Bates (University of Louisville, Louisville, KY).

\section{Cell Culture and Stable Transfection}

Mouse fibroblast L929 cells, LMCAT cells, and rat glioma $\mathrm{C} 6$ cells were grown in $175-\mathrm{cm}^{2}$ flasks at $37^{\circ} \mathrm{C}$ with $5 \%$ $\mathrm{CO}_{2}$ in ambient air. The LMCAT cell line was derived from L929 cells, which were stably transfected with a linked MMTV-LTR promoter and CAT reporter and a neomycin resistance gene. The L929 culture medium consisted of Dulbecco's Modified Eagle's Medium (DMEM) with $10 \%$ heat-inactivated $\left(56^{\circ} \mathrm{C}, 30 \mathrm{~min}\right.$ ) calf serum, 50 units $/ \mathrm{ml}$ penicillin, and $50 \mu \mathrm{g} / \mathrm{ml}$ streptomycin. The LMCAT culture medium was DMEM with $10 \%$ stripped newborn calf serum (charcoal/dextran-extracted, heat-inactivated) and $0.2 \mathrm{mg} / \mathrm{ml} \mathrm{G} 418$ sulfate (geneticin) antibiotic. For C6 cells, the culture medium was DMEM with $10 \%$ stripped fetal bovine serum, 50 units $/ \mathrm{ml}$ penicillin, $50 \mu \mathrm{g} / \mathrm{ml}$ streptomycin, and $0.2 \mathrm{mg} / \mathrm{ml}$ geneticin.

The C6 glioma cells were stably transfected with a pMMTVneo-LUC construct (GenBank Accession \# U02448) using Effectene (Qiagen) transfection reagent. The pMMTVneo-LUC plasmid contained the MMTV-LTR promoter and firefly luciferase reporter gene plus a neomycin resistance gene combined with a SV40 promoter. The resulting clonal cell line was denoted as C6LUC.B3.

For drug treatment, LMCAT and C6LUC.B3 cells were subcultured in fibronectin-coated 6-well plates and grown for $24 \mathrm{~h}$ to $95 \%$ final confluency. For binding assays, L929 cells were subcultured in $175-\mathrm{cm}^{2}$ flasks for $72-96 \mathrm{~h}$ to $95 \%$ final confluency before drug treatment or cell harvesting. Drug treatment consisted of incubation for $24 \mathrm{~h}$ with fresh medium containing the desired final concentrations of rolipram $(1 \mathrm{nM}$ to $10 \mu \mathrm{M})$, DMI $(10 \mu \mathrm{M})$, Dex (1 nM to $10 \mu \mathrm{M})$, and/or other pharmacological reagents (40 $\mu \mathrm{M}$ RU486). Appropriate vehicle controls were used in all experiments, and each experiment included at least three replicates of each treatment condition.

\section{CAT and Luciferase Assays}

The LMCAT cell line and the stably transfected C6 cell line contain a reporter gene (CAT and luciferase, respectively), which is inducible by glucocorticoids through the long terminal repeat (LTR) of the mouse mammary tumor virus promoter. The MMTV-LTR promoter contains multiple glucocorticoid response elements upstream of each reporter gene.

The induced CAT concentrations were measured by CAT ELISA (Roche Diagnostics, Indianapolis, IN) according to manufacturer's protocol. CAT levels were determined by colorimetry of a peroxidase plus substrate reaction, measured by absorption at 405 and 492 $\mathrm{nm}$ with a tunable plate reader (Molecular Devices). Before assay, the LMCAT cells were washed three times with cold phosphate buffered saline (PBS) and then lysed with the provided buffer. Cell extracts were 
spun at $23,000 \times \mathrm{g}$ and $4^{\circ} \mathrm{C}$ for $10 \mathrm{~min}$ to remove cellular debris.

The luciferase activity was measured with a microplate luminometer (Labsystems, Helsinki, Finland) and luciferin substrate (Promega, Madison, WI). The treated C6LUC.B3 cells were washed twice with cold PBS and then lysed with a passive lysis buffer. Cell extracts were spun at $23,000 \times \mathrm{g}$ and $4^{\circ} \mathrm{C}$ for $10 \mathrm{~min}$ to remove cellular debris.

The total protein content for all cell extracts was determined by bicinchoninic acid (BCA) assay (Pierce, Rockford, IL) with a tunable plate reader. Protein content values were used to normalize CAT and luciferase concentrations for potential variations in cell number.

\section{GR Binding Assay}

After incubation with drugs in $175-\mathrm{cm}^{2}$ flasks, the adherent L929 cells were washed three to five times with cold Hanks balanced salt solution (HBSS), scraped into cold HBSS, and transferred to centrifuge tubes. The cells were pelleted at $700 \times \mathrm{g}$ for $10 \mathrm{~min}$, resuspended in cold HBSS, and transferred to a new centrifuge tube. The cells were then pelleted at $700 \times \mathrm{g}$ for $15 \mathrm{~min}$ and stored at $-80^{\circ} \mathrm{C}$ after removing the HBSS.

GR binding was determined using a previously described in vitro cytosolic exchange assay (Miller et al. 1992). Cells were fractionated using a freeze/thaw procedure in a volume of $0.7 \mathrm{ml}$ of binding buffer $(10 \mathrm{mM}$ Tris, $1 \mathrm{mM}$ EDTA, $20 \mathrm{mM}$ molybdic acid, $5 \mathrm{mM}$ dithiothreitol, and $10 \%$ glycerol in double-distilled water, $\mathrm{pH}$ 7.4 at $4^{\circ}$ ), yielding an approximate final protein concentration of $0.5-2.5 \mathrm{mg} / \mathrm{ml}$ of cytosol. After centrifugation at $105,000 \times g$ for $60 \mathrm{~min}$ at $4^{\circ}$, the supernatant-cytosol was added to incubation solutions containing radiolabeled ${ }^{3} \mathrm{H}$-Dex with or without unlabeled Dex. Bound radiolabeled steroid was separated from unbound steroid by filtration through minicolumns containing $1.25 \mathrm{ml}$ of LH-20 Sephadex (Pharmacia, Piscataway, NJ). Eluant containing the bound fraction of steroid was added to scintillation fluor (Ultima Gold, Packard, Meriden, CT), and tritium ${ }^{3} \mathrm{H}$-radioactivity was determined in a Wallac LKB 1209 liquid scintillation counter (Uppsala, Sweden). Glucocorticoid receptor receptor binding was defined as the amount of total ${ }^{3} \mathrm{H}$-Dex $(20 \mathrm{nM})$ binding displaced by cold Dex $(5 \mu \mathrm{M})$. The amount of residual drug present in cell extracts was reduced by multiple cold HBSS washes after drug treatment. Incubations with ${ }^{3} \mathrm{H}$-Dex were carried out (at $\sim 20$-fold above the GR $\mathrm{K}_{\mathrm{d}}$ ) at $4^{\circ} \mathrm{C}$ for $18-22 \mathrm{~h}$ to establish binding equilibrium between the radiolabeled and cold Dex. Specific GR binding was expressed as $\mathrm{fmol} / \mathrm{mg}$ cytosolic protein. Protein content for all samples was determined according to the method of Bradford with use of BSA as a standard as described previously (Miller et al. 1992).

\section{Statistical Analysis}

All results are expressed as mean \pm SEM. Comparisons among treatment groups were made using 1-factor or 2 -factor analysis of variance (ANOVA). Post hoc comparisons of specific means were made using both conservative (Tukey) and powerful (Student's t) tests of significance. When both tests were significant only results of the Tukey test are reported. Non-parametric tests of significance were used (e.g. Kruskal-Wallis oneway ANOVA on Ranks, Mann Whitney Rank Sum Test, Dunn's Method) in cases where the data were not normally distributed. All tests of significance were 2-tailed with an $\alpha$ level of .05 .

\section{RESULTS}

As shown in Figure 1 (panels A and B), both Dex and drug treatment (rolipram and DMI) had a significant main effect on GR-mediated gene transcription in LMCAT cells $\left(\mathrm{F}_{1,120}=183.7, p<.001\right.$ and $\mathrm{F}_{2,120}=8.6, p<$ .001 , respectively). Rolipram alone led to a significant increase in the activity of the CAT reporter gene compared with vehicle-treated cells $(p<.05)$ (Panel A), whereas desipramine slightly but significantly decreased CAT activity $p<.05)$. Treatment with rolipram $(10 \mu \mathrm{M})$ in combination with dexamethasone (Dex) resulted in a significant enhancement of Dex (10 nM)induced GR-mediated gene transcription in LMCAT cells $(p<.01)$ (Panel B), similar to that seen (and previously reported) with desipramine $(10 \mu \mathrm{M})(p<.01)$ (Pariante et al. 1997). Dose response studies (Figure 2) revealed a significant main effect of rolipram treatment on CAT reporter gene activity $(\mathrm{H}=26.7, \mathrm{df}=5, p<$ .001) with rolipram alone leading to a dose dependent increase in GR-mediated gene transcription that achieved statistical significance beginning at a concentration of $10^{-7} \mathrm{M}(0.1 \mu \mathrm{M})$ (Figure 2, panel A). Rolipram treatment also had a significant main effect on Dexinduced GR-mediated gene transcription $\left(\mathrm{F}_{4,13}=14.2, p<\right.$ .001) (Figure 3, panel A) with the combination of Dex (1nM and $10 \mathrm{nM})$ plus rolipram $(10 \mu \mathrm{M})$ leading to significant enhancement in CAT activity $(p<.05)$ (Figure 3, panel A). Of note, higher concentrations of Dex $(0.1 \mu \mathrm{M}-10 \mu \mathrm{M})$ in combination with rolipram $(10 \mu \mathrm{M})$ revealed no enhancement of reporter enzyme activity.

Because cAMP pathways have been implicated in the regulation of membrane steroid transporters such as the p-glycoprotein multiple drug resistance (MDR) pump (which pumps out synthetic steroids including Dex and endogenous steroids including cortisol) (Sharom 1997; Pariante et al. 2001a), we examined the effects of rolipram on CAT activity in LMCAT cells treated with corticosterone, which is not a substrate for the pump (Sharom 1997; Pariante et al. 2001a). Similar 


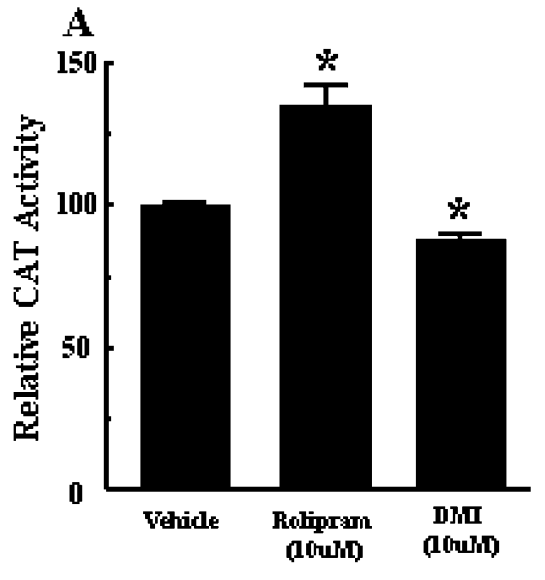

Treatment

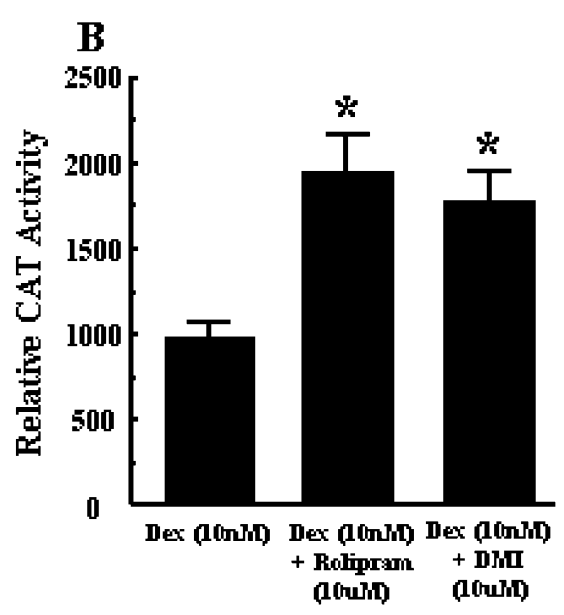

Treatment

Figure 1. Rolipram enhancement of basal and Dex-induced CAT activity in LMCAT cells. CAT activity was measured following $24 \mathrm{~h}$ treatment of LMCAT mouse fibroblast cells with vehicle, $10 \mu \mathrm{M}$ rolipram, or $10 \mu \mathrm{M}$ DMI alone (A) or in combination with $10 \mathrm{nM}$ Dex (B). Relative CAT activity is the percent increase/decrease in CAT activity compared with vehicle control. Values (MEAN \pm SEM) are the result of seven independent experiments. *significantly different from vehicle alone using the Mann Whitney Rank Sum test or student's t-test $(p<.05)$ (A). *significantly different from Dex alone using the Mann Whitney Rank Sum test $(p<.01)$ (B). DMI $=$ desipramine, Dex $=$ dexamethasone.

to the results with Dex, rolipram had a significant main effect on corticosterone-induced GR-mediated gene transcription $\left(\mathrm{F}_{4,14}=4.8, p<.025\right)$, significantly enhancing the effects of corticosterone on LMCAT cell CAT activity at lower concentrations ( 1 and $10 \mathrm{nM}$ ) of corticosterone $(p<.05)$ but not at higher concentrations $(0.1$ $\mu \mathrm{M}-10 \mu \mathrm{M})$ (Figure 3, panel B).

To determine whether the effects of rolipram generalize to other cell types (e.g. neural cells), rolipram alone $(10 \mu \mathrm{M})$ or in combination with Dex (1 and 10nM) was administered for $24 \mathrm{~h}$ to C6 glioma cells stably transfected with a luciferase reporter gene construct with an upstream MMTV promoter containing multiple GREs. As in LMCAT mouse fibroblasts, both Dex and rolipram treatment had a significant main effect on luciferase reporter gene activity $\left(\mathrm{F}_{2,53}=739.3, p<.001\right.$ and $\mathrm{F}_{1,53}=14.6, p<.001$, respectively). Compared with vehicle treatment, rolipram $(10 \mu \mathrm{M})$ treatment alone significantly enhanced luciferase activity $(p<.01)$, and the combination of rolipram $(10 \mu \mathrm{M})$ plus Dex (1 or 10 $\mathrm{nM})$ led to significantly greater luciferase activity than Dex alone $(p<.01)$ (Figure 4$)$.

To examine the receptor specificity of the effects of rolipram on dexamethasone-induced CAT activity, the effects of rolipram plus dexamethasone were measured in the presence and absence of the glucocorticoid receptor antagonist, RU486 $(40 \mu \mathrm{M})$, in LMCAT cells. As shown in Figure 5, both Dex and drug treatment (rolipram and RU486) had a significant main effect on reporter gene activity $\left(\mathrm{F}_{1,71}=88.0, p<.001\right.$ and $\mathrm{F}_{3,71}=$ $28.8, p<.001$, respectively). Relevant to the role of the
GR in rolipram-mediated effects, the addition of RU486 significantly reduced the effect of rolipram $(10 \mu \mathrm{M})$ plus dexamethasone $(10 \mathrm{nM})$ on CAT activity $(p<.001)$. Interestingly, our previous studies have shown that 24 $\mathrm{h}$ incubation with RU486 slightly but significantly increases GR-mediated gene transcription (Pariante et al. 2001b). Consistent with previous studies of activators of protein kinase A, the addition of rolipram to RU486 significantly enhanced this effect of RU486 compared with RU486 alone $(p<.005)$ (Nordeen et al. 1993).

To determine whether rolipram enhancement of GRmediated gene transcription was associated with an upregulation in GR protein, GR binding was determined in L929 cells treated with rolipram alone, dexamethasone alone, or the combination. As shown in Figure 6, there was a significant main effect of treatment condition on cytosolic GR binding $\left(\mathrm{F}_{3,35}=5.2, p<.005\right)$. Glucocorticoid receptor binding was significantly decreased in rolipram $(10 \mu \mathrm{M})$-treated L929 cells compared with vehicle-treated controls $(p<.025)$. In addition, rolipram $(10 \mu \mathrm{M})$ plus Dex $(10 \mathrm{nM})$ exhibited a greater reduction in cytosolic receptor binding compared with vehicle than Dex treatment alone.

Finally, to examine whether rolipram influences the effect of DMI on Dex-induced GR-mediated gene transcription, rolipram $(10 \mu \mathrm{M})$ and DMI $(10 \mu \mathrm{M})$ were administered to LMCAT cells alone and in combination with Dex $(10 \mathrm{nM})$. As shown in Figure 7, panel A, treatment condition had a significant main effect on Dexinduced GR-mediated gene transcription $(\mathrm{H}=32.2, \mathrm{df}=$ $3, \mathrm{p}<.001)$. Rolipram synergized with DMI to lead to 


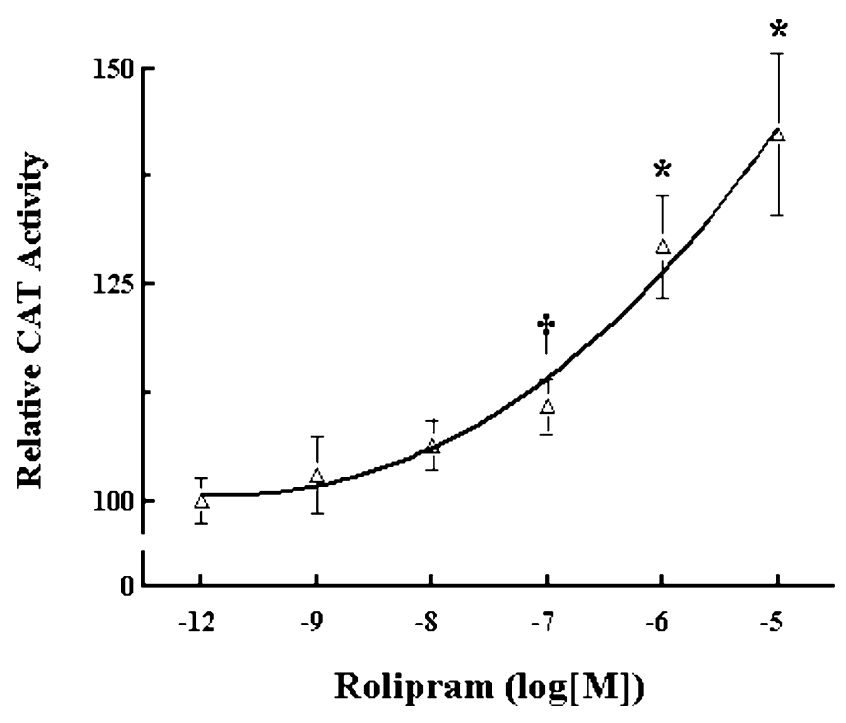

Figure 2. Dose dependent enhancement of basal CAT activity by rolipram in LMCAT cells. CAT activity was measured in LMCAT mouse fibroblast cells following $24 \mathrm{~h}$ treatment with various concentrations of rolipram. Relative CAT activity is the percent increase in CAT activity compared with vehicle control. Values (MEAN \pm SEM) are the results of three independent experiments. *significantly different from vehicle using Dunn's method $(p<.05)$. ' different from vehicle using student's $t$-test $(p<.025)$.

an 8-fold increase in GR-mediated gene transcription compared with Dex treatment alone $(p<.05)$. Because DMI effects on GR-mediated gene transcription have been attributed to inhibition of the MDR pump (Pariante et al. 2001a), we examined the impact of rolipram plus DMI using corticosterone as the steroid ligand (10 $\mathrm{nM})$. As noted above, corticosterone is not a substrate for the pump. As shown in Figure 7, panel B, treatment condition had a significant main effect on corticosterone-induced GR-mediated gene transcription $(\mathrm{H}=$ $23.78, \mathrm{df}=3, p<.001$ ). Of note, however, only rolipram exhibited a significant effect on corticosterone-induced reporter gene activity $(p<.05)$, and no further enhancement was observed when DMI was added.

\section{DISCUSSION}

The results of this study demonstrate that in addition to enhancing Dex-induced GR-mediated gene transcription, the PDE type 4 inhibitor, rolipram, significantly increased GR-mediated gene transcription in the relative absence of glucocorticoid hormone. Rolipram effects on Dex-induced GR-mediated gene transcription appear to be mediated through the GR as demonstrated by reversal of the effects following administration of the GR antagonist, RU486. Finally, rolipram does not appear to

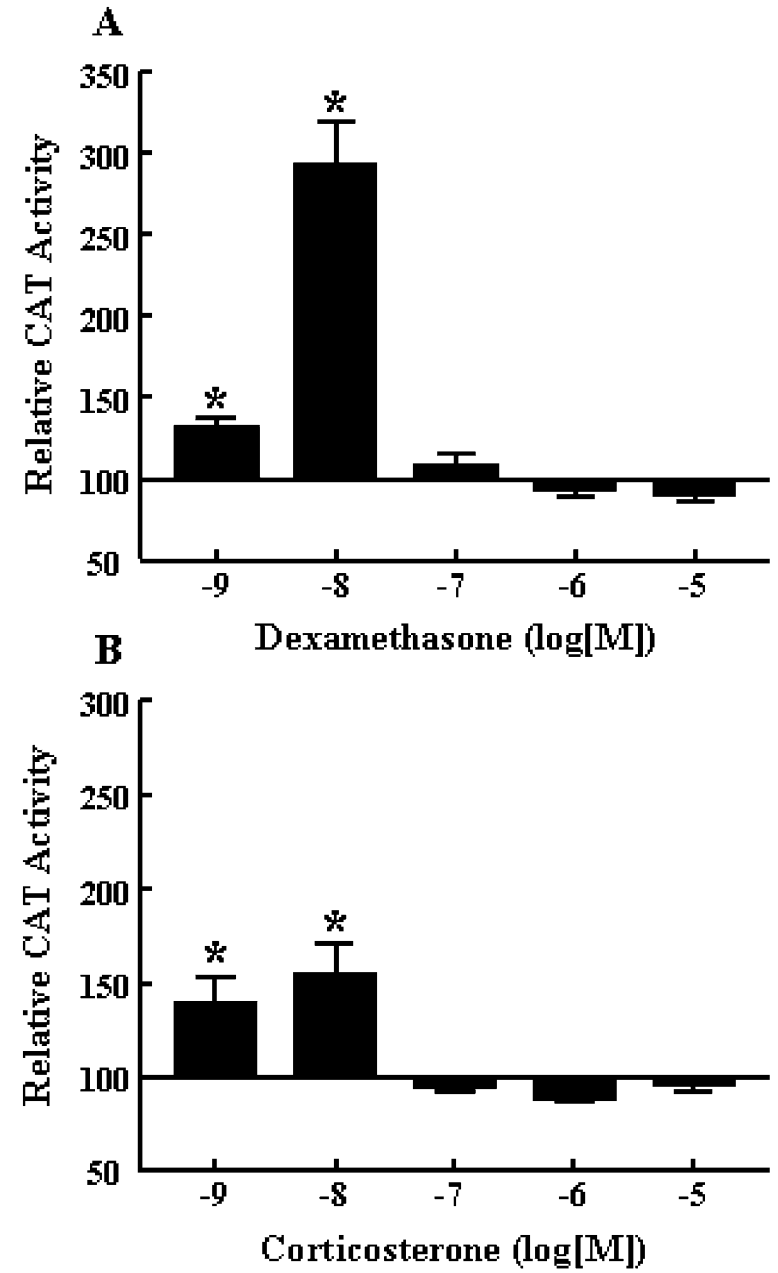

Figure 3. Rolipram enhancement of Dex- and corticosterone-induced CAT activity in LMCAT cells. A. CAT activity was measured in LMCAT mouse fibroblast cells following $24 \mathrm{~h}$ treatment with various concentrations of Dex alone or in combination with rolipram $(10 \mu \mathrm{M})$. Relative CAT activity is the percent increase/decrease in CAT activity in cells treated with rolipram plus Dex compared with cells treated with Dex alone at the indicated concentration. Values (mean \pm SEM) are the results of three independent experiments. *significantly different from Dex alone using the Mann Whitney Rank Sum Test or the student's $t$-test $(p<.05)$. B. CAT activity was measured in LMCAT cells following $24 \mathrm{~h}$ treatment with various concentrations of corticosterone alone or in combination with rolipram $(10 \mu \mathrm{M})$. Relative CAT activity is the percent increase/decrease in CAT activity in cells treated with rolipram plus corticosterone compared with cells treated with corticosterone alone at the indicated concentration. Values (mean \pm SEM) are the results of four independent experiments. *significantly different from corticosterone alone using the Mann Whitney Rank Sum Test $(p<$ .05). Dex = dexamethasone. 


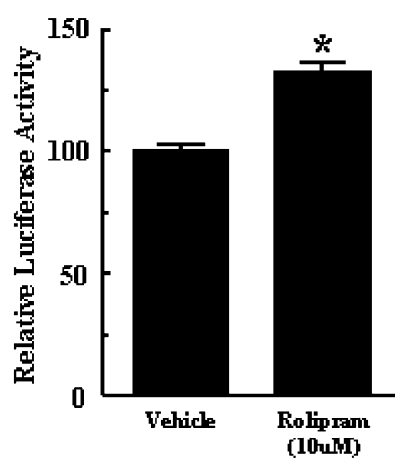

Treatment

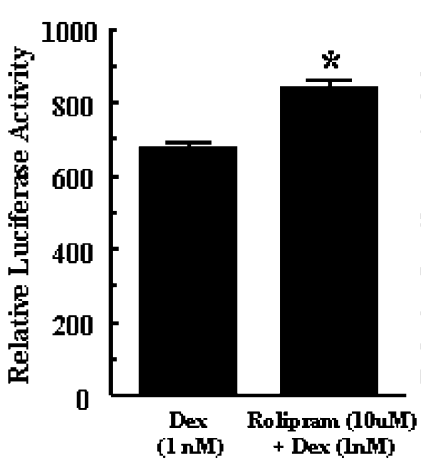

Treatment

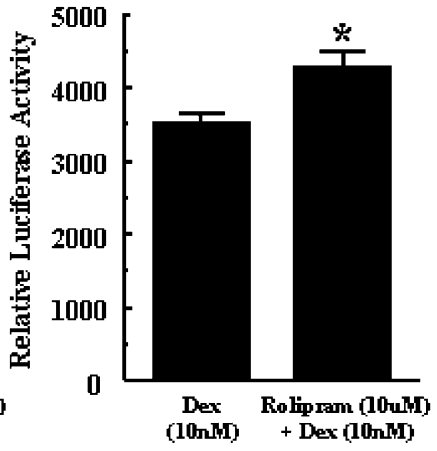

Treatment

Figure 4. Rolipram enhancement of Dex-induced luciferase activity in stably transfected C6 glioma cells. Rat C6 glioma cells were stably transfected with a combined MMTV promoter and luciferase reporter with a geneticin selection marker. Luciferase activity was measured following $24 \mathrm{~h}$ treatment of C6 cells with various combinations of vehicle, $10 \mu \mathrm{M}$ rolipram, and 1 and $10 \mathrm{nM}$ Dex. Relative luciferase activity is the percent increase/decrease in luciferase activity compared with vehicle control. Values (mean \pm SEM) are the results of three independent experiments. *significantly different from the respective non-rolipram treated cells using student's $t$-test $(p<.01)$. Dex $=$ dexamethasone.

act through GR upregulation. In fact, cytosolic receptor binding studies indicated that rolipram, like other antidepressants, influences compartmentalization of the GR by inducing GR nuclear translocation.

A number of studies have documented the wideranging effects of rolipram on cellular activity in both the immune system and the brain. Immunologic studies have shown that rolipram has potent antiinflammatory effects, exhibiting inhibition of the proinflammatory cytokine, TNF- $\alpha$, and providing protection from several autoimmune disorders (Ross et al. 1997; Laemont et al. 1999; Kung et al. 2000; Pang and Knox 2000, 2001; Sekut et al. 1995; Eigler et al. 1998; Sommer et al. 1997). Indeed, it has been suggested that rolipram may serve as an effective therapy for human autoimmune disorders, including multiple sclerosis (Sommer et al. 1997). Relevant to the results of this study, glucocorticoids are a mainstay in the treatment of autoimmune disorders and also have well known antiinflammatory effects including profound inhibition of TNF- $\alpha$ (Sternberg 2001).

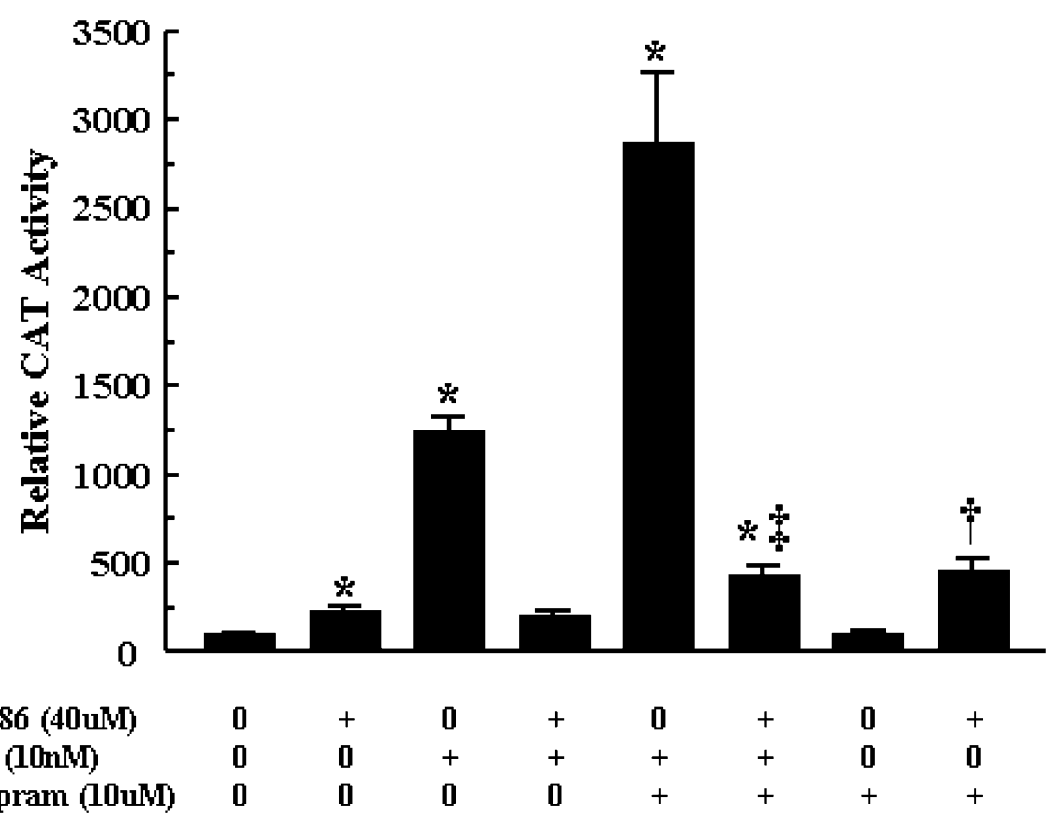

Figure 5. Reversal of rolipram enhancement of Dex-induced CAT activity by the GR antagonist, RU486. CAT activity was measured in LMCAT mouse fibroblast cells treated for $24 \mathrm{~h}$ with various combinations of RU486 (40 $\mu \mathrm{M})$, Dex (10 nM) and rolipram (10 $\mu \mathrm{M})$. Relative CAT activity is the percent increase in CAT activity compared with vehicle control. Values (mean \pm SEM) are the results of three independent experiments. *significantly different from vehicle control using a student's $t$-test or Mann Whitney Rank Sum Test $(p<.01)$. 'significantly different from RU486 alone using a student's $t$-test $(p<.005)$. ${ }^{\ddagger}$ significantly different from rolipram plus dexamethasone using the Mann Whitney Rank Sum Test $(p<.001)$. Dex $=$ dexamethasone. 


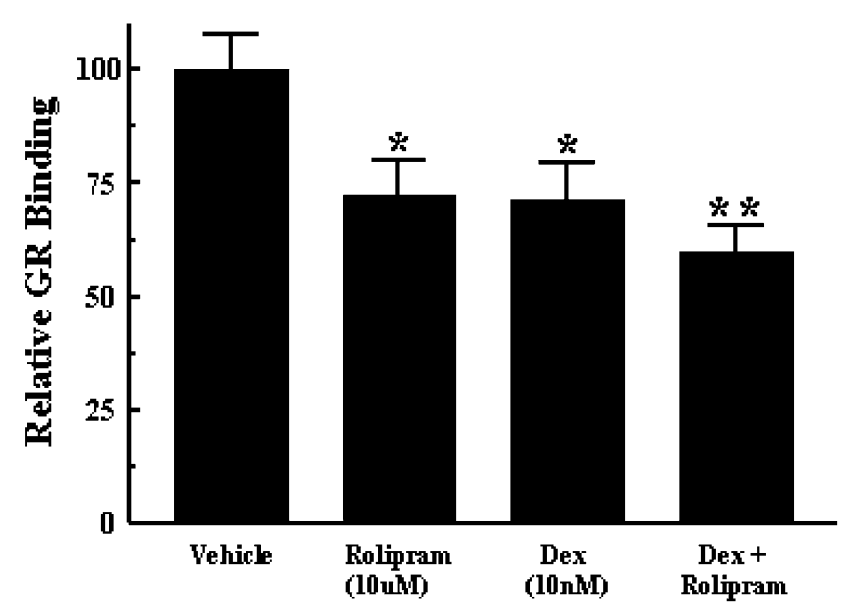

Treatment

Figure 6. Reduction of cytosolic GR binding in L929 cells by rolipram. L929 mouse fibroblast cells were treated for 24 $\mathrm{h}$ with vehicle, $10 \mathrm{nM}$ Dex, $10 \mu \mathrm{M}$ rolipram, or $10 \mathrm{nM}$ Dex plus $10 \mu \mathrm{M}$ rolipram. Single-point binding data using $\left[{ }^{3} \mathrm{H}\right]-$ dexamethasone are displayed as the percent of control (vehicle). Results (mean \pm SEM) were pooled from three independent experiments. *significantly different from vehicle control using the student's $t$-test $(p<.025)$. ${ }^{* *}$ significantly different from vehicle control using the Tukey test $(p<.05)$. Dex $=$ dexamethasone.

Based on the capacity of rolipram to enhance GR function, one might wonder whether rolipram effects on inflammation are mediated in part through an effect on the GR. At least two studies have addressed this possibility, and both provide evidence consistent with the data reported herein. In one study, the inhibitory effect of rolipram on TNF- $\alpha$ induction during streptococcal cell wall-induced arthritis was reversed by the GR antagonist, RU486 (Laemont et al. 1999). In another study, the glucocorticoid synthesis inhibitor, metyrapone, was found to attenuate rolipram-induced inhibition of pulmonary eosinophilia in allergic mice (Kung et al. 2000). Complementing these studies are a number of reports demonstrating comparable immunologic effects of glucocorticoids and rolipram on cytokine induction (decreased TNF- $\alpha$ and increased interleukin (IL)-10 and IL4) as well as inflammation (e.g. reduced macrophage activation and nitric oxide production) (Sekut et al. 1995; Eigler et al. 1998; Sternberg 2001; Abbas et al. 2000; Daynes and Araneo 1989; Yang et al. 1998; Beshay et al. 2001; Swain et al. 1999; Gayo et al. 1998). Moreover, there have been two recent reports of synergistic actions of glucocorticoids and rolipram on the release of eotaxin, a potent eosinophil chemoattractant, from human airway smooth muscle cells (Pang and Knox 2000, 2001).
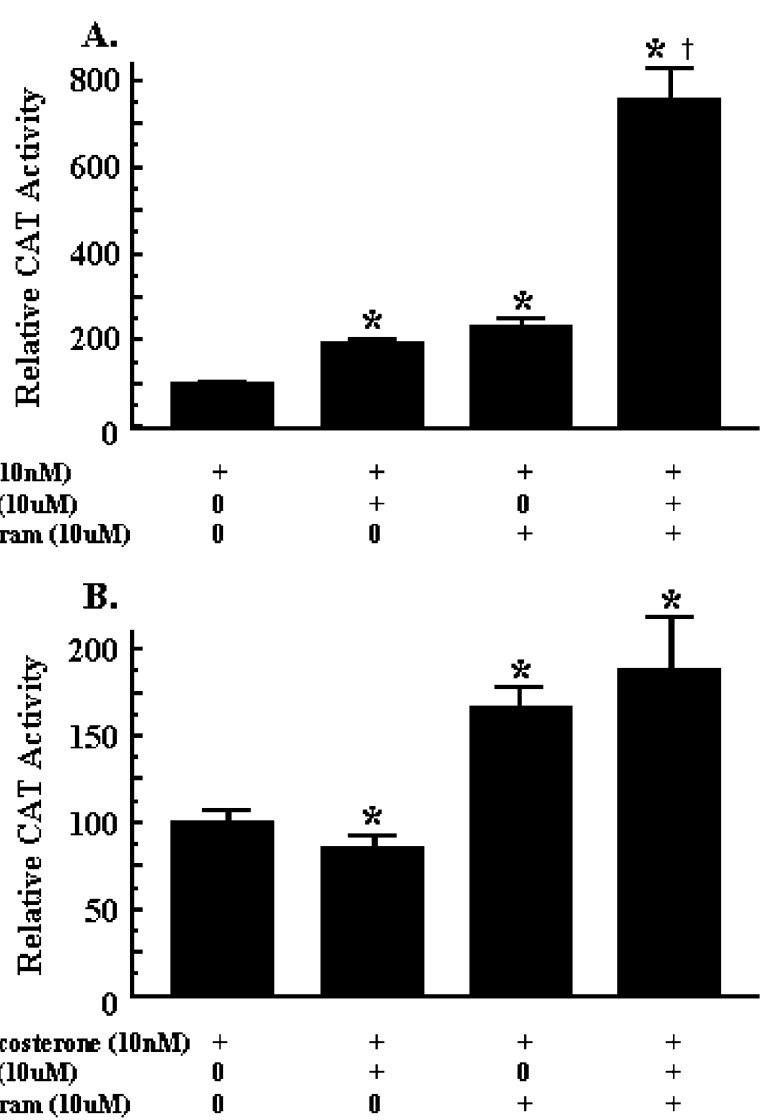

Figure 7. Potentiation of Dex-induced CAT activity following co-treatment with rolipram and DMI. CAT activity was measured in LMCAT mouse fibroblast cells treated with various combinations of rolipram $(10 \mu \mathrm{M})$, DMI $(10 \mu \mathrm{M})$, Dex $(10 \mathrm{nM})$ and corticosterone $(10 \mathrm{nM})$. Relative CAT activity is the percent increase/decrease in CAT activity compared with Dex (A) or corticosterone (B) alone. Values (Mean \pm SEM) are the results of three independent experiments. *significantly different from Dex alone or corticosterone alone using Dunn's Method, Mann Whitney Rank Sum Test or student's $t$-test $(p<.05)$. ' significantly different from all other groups using Dunn's method $(p<.05)$. DMI $=$ desipramine, Dex = dexamethasone.

In addition to rolipram effects on the immune system, there has been interest in rolipram and the cAMP cascade in the regulation of nerve growth factors, especially the regulation of brain derived neurotrophic factor (BDNF) during antidepressant treatment (Nibuya et al. 1996). This area of investigation (especially regarding the use of PDE type 4 inhibitors like rolipram) has yet to be extensively developed. Nevertheless, glucocorticoids and activators of the cAMP cascade including $\beta$-receptor agonists, forskolin and 8-bromo-cAMP have demonstrated similar effects on nerve growth factor (NGF), basic fibroblast growth factor (bFGF), and BDNF when studied under conditions of acute exposure (Colangelo et al. 1998; Hayes et al. 1995; Yama- 
moto et al. 1993; Grundy et al. 2001; Mocchetti et al. 1996). Interestingly, adrenalectomy abolished the effects of the $\beta$-receptor agonist, isoproterenol, on upregulation of NGF and bFGF mRNA in the brain, indicating that $\beta$-agonist effects on growth factor expression in the brain are in part dependent on glucocorticoids (Follesa and Mocchetti 1993). More study is needed to determine the relative role of the effects of rolipram on the GR in mediating longer term effects of rolipram on nerve growth factors, especially in vivo where rolipram enhancement of GR function may reduce prevailing levels of hormone secondary to increased GR-mediated feedback inhibition. Such rolipram-induced changes in prevailing hormone may in turn influence growth factor expression.

Given the dual action of rolipram on the GR and the immune system (which appear to be related), rolipram in particular, and type 4 PDE inhibitors in general, may be especially useful for targeting behavioral complications in patients with comorbid neuropsychiatric and immunologic disorders including autoimmune disorders and infectious diseases. Studies indicate a high rate of depression in patients with a wide range of autoimmune disorders (Mahler 1992; Moran 1996). In addition, ample evidence indicates that patients with major depression and/or autoimmune disorders exhibit impaired GR-mediated feedback inhibition (glucocorticoid resistance) (Pariante and Miller 2001; Holsboer 2000; Miller et al. 1999). Consequences of this altered feedback include unrestrained release of behaviorally active neuropeptides including $\mathrm{CRH}$ and pro-inflammatory cytokines including TNF- $\alpha$, IL-1, and IL-6 (Pariante and Miller 2001; Miller et al. 1999). Elevations in CRH have been demonstrated in depressed patients, as have elevations in proinflammatory cytokines, especially in medically ill (i.e. cancer) patients who are depressed (Pariante and Miller 2001; Owens and Nemeroff 1993; Maes 1999; Musselman et al. 2001). Of note, pro-inflammatory cytokines are potent stimulators of $\mathrm{CRH}$ and may contribute to impaired glucocorticoid-mediated feedback through direct inhibitory effects on the GR (Miller et al. 1999; Pariante et al. 1999). Moreover, proinflammatory cytokines have been shown to contribute to a syndrome of "sickness behavior," which shares many features in common with major depression including anhedonia, fatigue, anorexia, altered sleep, and impaired cognition (Kent et al. 1992). Thus, rolipram facilitation of GR-mediated feedback inhibition may serve to reverse glucocorticoid resistance and restrain both CRH and cytokine responses, thereby addressing behavioral alterations in comorbid mood and immunerelated disorders. The synergism of rolipram with other antidepressants (in this case desipramine), also suggests that rolipram may be especially useful in combination with other antidepressant agents (especially those that exhibit some activity on GR function).
Our findings with rolipram are consistent with a rich literature demonstrating that downstream elements of the cAMP cascade can enhance GR function. More recent studies have demonstrated that upstream activators of this cascade, including the $\beta$-agonists, epinephrine and norepinephrine, can also directly modulate GR function (Eickelberg et al. 1999; Schmidt et al. 2001). While studies have yielded conflicting results regarding the capacity of these upstream factors to activate the GR in the absence of steroid ligand $(9,10)$, we provide data indicating, that in contradistinction to the antidepressant desipramine, rolipram does appear to be able to activate the GR in the absence of hormone (Pariante et al. 1997). Nevertheless, since steroid stripping of serum can never be absolute, it remains possible that rolipram will only exhibit its effect in the presence of some ligand, albeit a small amount.

Although the downstream signaling pathways responsible for rolipram's effect on GR have yet to be elucidated, clues regarding the mechanism of rolipram's effects are provided by the data. First, recent work indicates that the enhancement of Dex-induced, GRmediated gene transcription by antidepressants including DMI, amitryptiline, clomipramine, paroxetine and citalopram is mediated through inhibition of membrane steroid transporters, including the MDR pump, which pump steroids such as dexamethasone and cortisol out of the cell (Sharom 1997; Pariante et al. 2001a). Inhibition of the pump by antidepressants serves to increase intracellular concentrations of steroid ligand and thus increase steroid bioactivity. Corticosterone is not a substrate for membrane steroid transporters and has been used to reveal pump-related effects on GR function by other antidepressants (Pariante et al. 2001a). Interestingly, however, unlike other antidepressants, rolipram was found to enhance corticosterone-induced GR-mediated gene transcription., indicating that rolipram effects on the GR are not mediated through inhibition of the pump. Second, although increased GR expression could potentially account for increased GR-mediated reporter gene activity, no evidence of GR upregulation was found. In fact, a decrease in cytosolic GR binding was observed, suggesting that rolipram may act by enhancing nuclear translocation of the receptor.

In summary, PDE type 4 inhibitors as embodied by rolipram, appear to be an interesting group of pharmacologic compounds whose spectrum of activity has been extended herein to include the GR. Rolipram effects on the GR appear to contribute to its effects on immune function and may extend to more recent considerations regarding nerve growth factors. Given its multiplicity of activity (based in part on its direct action on signal transduction), rolipram (and other type 4 PDE inhibitors) may be especially useful in patients with both immunologic and neuropsychiatric disorders, and may act synergistically with other antidepressant agents. 


\section{ACKNOWLEDGMENTS}

This work was supported in part by grants from the National Institute of Mental Health (MH00680 and MH47674-08), the National Alliance for Research on Schizophrenia and Depression (AHM: van Ameringen Investigator), and the Woodruff Fund. The authors would like to express their appreciation to Cindy Su for her technical assistance in the project, and Carmine M. Pariante, M.D. for his helpful discussion of the impact of antidepressants on membrane steroid transporters.

\section{REFERENCES}

Abbas N, Zou LP, Pelidou SH, Winblad B, Zhu J (2000): Protective effect of Rolipram in experimental autoimmune neuritis: protection is associated with down-regulation of IFN-gamma and inflammatory chemokines as well as up-regulation of IL-4 in peripheral nervous system. Autoimmunity 32:93-99

Beavo JA, Conti M, Heaslip RJ (1994): Multiple cyclic nucleotide phosphodiesterases. Mol Pharmacol 46:399-405

Beshay E, Croze F, Prud'homme GJ (2001): The phosphodiesterase inhibitors pentoxifylline and rolipram suppress macrophage activation and nitric oxide production in vitro and in vivo. Clin Immunol 98:272-279

Bobon D, Breulet M, Gerard-Vandenhove M-A, GuitoGoffioul F, Plomteux G, Satre-Hernandez M, Schratzer M, Troisfontaines B, von Frenckell R, Wachtel H (1988): Is phosphodiesterase inhibitor a new mechanism of antidepressant action? Eur Arch Psychiatr Neurol Sci 238:2-6

Chen J, Rasenick MM (1995a): Chronic treatment of C6 glioma cells with antidepressant drugs increases functional coupling between a $G$ protein (Gs) and adenylyl cyclase. J Neurochem 64:724-732

Chen J, Rasenick MM (1995b): Chronic antidepressant treatment facilitates $G$ protein activation of adenylyl cyclase without altering $G$ protein content. J Pharmacol Exp Ther 275:509-517

Colangelo AM, Follesa P, Mocchetti I (1998): Differential induction of nerve growth factor and basic fibroblast growth factor mRNA in neonatal and aged rat brain. Brain Res Mol Brain Res 53:218-225

Daynes RA, Araneo BA (1989): Contrasting effects of glucocorticoids on the capacity of $\mathrm{T}$ cells to produce the growth factors interleukin 2 and interleukin 4. Eur J Immunol 19:2319-2325

Eckmann F, Fichte K, Meya U, Sastre-Y-Hernandez M (1988): Rolipram in major depression: results of a double blind comparative study with amitriptyline. Current Therapeutic Res 43:291-295

Eickelberg O, Roth M, Lorx R, Bruce V, Rudiger J, Johnson M, Block L-H (1999): Ligand-independent activation of the glucocorticoid receptor by Beta2-adrenergic receptor agonists in primary human lung fibroblasts and vascular smooth muscle cells. J Biol Chem 274:1005-1010

Eigler A, Siegmund B, Emmerich U, Baumann KH, Hartmann G, Endres S (1998): Anti-inflammatory activities of cAMP-elevating agents: enhancement of IL-10 synthesis and concurrent suppression of TNF production. J Leukoc Biol 63:101-107
Engels P, Fichtel K, Lübbert H (1994): Expression and regulation of human and rat phosphodiesterase type 4 isogenes. FEBS Lett 350:291-295

Follesa P, Mocchetti I (1993): Regulation of basic fibroblast growth factor and nerve growth factor mRNA by betaadrenergic receptor activation and adrenal steroids in rat central nervous system. Mol Pharmacol 43:132-138

Gayo A, Mozo L, Suarez A, Tunon A, Lahoz C, Gutierrez C (1998): Glucocorticoids increase IL-10 expression in multiple sclerosis patients with acute relapse. J Neuroimmunol 85:122-130

Grundy PL, Patel N, Harbuz MS, Lightman SL, Sharples PM (2001): Glucocorticoids modulate the NGF mRNA response in the rat hippocampus after traumatic brain injury. Brain Res 892:386-390

Hayes VY, Isackson PJ, Fabrazzo M, Follesa P, Mocchetti I (1995): Induction of nerve growth factor and basic fibroblast growth factor mRNA following clenbuterol: contrasting anatomical and cellular localization. Exp Neurol 132:33-41

Holsboer F (2000): The corticosteroid receptor hypothesis of depression. Neuropsychopharmacology 23:477-501

Holsboer F, Barden N (1996): Antidepressants and hypothalamic-pituitary-adrenocortical regulation. Endocr Rev 17:187-205

Kent S, Bluthe RM, Kelley KW, Dantzer R (1992): Sickness behavior as a new target for drug development. Trends Pharmacol Sci 13:24-28

Kung TT, Crawley Y, Luo B, Young S, Kreutner W, Chapman RW (2000): Inhibition of pulmonary eosinophilia and airway hyperresponsiveness in allergic mice by rolipram: involvement of endogenously released corticosterone and catecholamines. Br J Pharmacol 130:457463

Laemont KD, Schaefer CJ, Juneau PL, Schrier DJ (1999): Effects of the phosphodiesterase inhibitor rolipram on streptococcal cell wall-induced arthritis in rats. Int J Immunopharmacol 21:711-725

Maes M (1999): Major depression and activation of the inflammatory response system. Adv Exp Med Biol 461: 25-46

Mahler ME (1992): Behavioral manifestations associated with multiple sclerosis. Psychiatr Clin North Am 15:427-438

Miller AH, Pariante CM, Pearce BD (1999): Effects of cytokines on glucocorticoid receptor expression and function: glucocorticoid resistance and relevance to depression. Adv Exp Med Biol 461:107-116

Miller AH, Spencer RL, Pulera M, Kang S, McEwen BS, Stein M (1992): Adrenal steroid receptor activation in rat brain and pituitary following dexamethasone: implications for the dexamethasone suppression test. Biol Psychiatry 32:850-869

Mocchetti I, Spiga G, Hayes VY, Isackson PJ, Colangelo A (1996): Glucocorticoids differentially increase nerve growth factor and basic fibroblast growth factor expression in the rat brain. J Neurosci 16:2141-2148

Moran MG (1996): Psychiatric aspects of rheumatology. Psychiatr Clin North Am 19:575-587

Musselman DL, Miller AH, Porter MR, Manatunga A, Gao F, Penna S, Pearce BD, Landry J, Glover S, McDaniel JS, Nemeroff CB (2001): Higher than normal plasma inter- 
leukin-6 concentrations in cancer patients with depression: preliminary findings. Am J Psychiatry 158:12521257

Nestler EJ, Terwilliger RZ, Duman RS (1989): Chronic antidepressant administration alters the subcellular distribution of cyclic AMP-dependent protein kinase in rat frontal cortex. J Neurochem 53:1644-1647

Nibuya M, Nestler EJ, Duman RS (1996): Chronic antidepressant administration increases the expression of cAMP response element binding protein (CREB) in rat hippocampus. J Neurosci 16:2365-2372

Nordeen SK, Bona BJ, Moyer ML (1993): Latent agonist activity of the steroid antagonist, RU486, is unmasked in cells treated with activators of protein kinase A. Mol Endocrinol 7:731-742

Owens MJ, Nemeroff CB (1993): The role of CRF in the pathophysiology of affective disorders: laboratory and clinical studies. In Vale WW (ed), Ciba Foundation Symposium on Corticotropin-Releasing Factor, 172. New York, John Wiley \& Sons, pp 293-316

Pang L, Knox AJ (2000): Synergistic inhibition by beta(2)agonists and corticosteroids on tumor necrosis factoralpha-induced interleukin-8 release from cultured human airway smooth-muscle cells. Am J Respir Cell Mol Biol 23:79-85

Pang L, Knox AJ (2001): Regulation of TNF-alpha-induced eotaxin release from cultured human airway smooth muscle cells by beta2-agonists and corticosteroids. FASEB J 15:261-269

Pariante CM, Makoff A, Lovestone S, Feroli S, Heyden A, Miller AH, Kerwin RW (2001a): Antidepressants enhance glucocorticoid receptor function in vitro by modulating the membrane steroid transporters. Br J Pharmacol 134:1335-1343

Pariante CM, Miller AH (2001): Glucocorticoid receptors in depression: relevance to pathophysiology and treatment. Biol Psychiatry 49:391-404

Pariante CM, Pearce BD, Pisell TL, Owens MJ, Miller AH (1997): Steroid-independent translocation of the glucocorticoid receptor by the antidepressant desipramine. Mol Pharmacol 52:571-581

Pariante CM, Pearce BD, Pisell TL, Sanchez CI, Po C, Su C, Miller AH (1999): The proinflammatory cytokine, interleukin-1 alpha, reduces glucocorticoid receptor translocation and function. Endocrinology 140:4359-4366

Pariante CM, Pearce BD, Pisell TL, Su C, Miller AH (2001b): The steroid receptor antagonists, RU40555 and RU486, activate glucocorticoids receptor translocation and are not excreted by the steroid hormones transporter in L929 cells. J Endocrinol 169:309-320

Perez-Torres S, Miro X, Palacios JM, Cortes R, Puigdomenech P, Mengod G (2000): Phosphodiesterase type 4 isozymes expression in human brain examined by in situ hybridization histochemistry and[3H]rolipram bind- ing autoradiography. Comparison with monkey and rat brain. J Chem Neuroanat 20:349-74

Rangarajan PN, Umesono K, Evans RM (1992): Modulation of glucocorticoid receptor function by protein kinase A. Mol Endocrinol 6:1451-1457

Ross SE, Williams RO, Mason LJ, Mauri C, MarinovaMutafchieva L, Malfait AM, Maini RN, Feldmann M (1997): Suppression of TNF-alpha expression, inhibition of Th1 activity, and amelioration of collagen-induced arthritis by rolipram. J Immunol 159:6253-6259

Sato A, Sheppard KE, Fullerton MJ, Funder JW (1996): cAMP modulates glucocorticoid-induced protein accumulation and glucocorticoid receptor in cardiomyocytes. Am J Physiol 271:E827-833

Schmidt P, Holsboer F, Spengler D (2001): [beta]2-adrenergic receptors potentiate glucocorticoid receptor transactivation via $G$ protein [beta][gamma]-subunits and the phosphoinositide 3-kinase pathway. Mol Endocrinol 15:553-564

Sekut L, Yarnall D, Stimpson SA, Noel LS, Bateman-Fite R, Clark RL, Brackeen MF, Menius JA Jr, Connolly KM (1995): Anti-inflammatory activity of phosphodiesterase (PDE)-IV inhibitors in acute and chronic models of inflammation. Clin Exp Immunol 100:126-132

Sharom FJ (1997): The P-glycoprotein efflux pump: how does it transport drugs? J Membr Biol 160:161-175

Sommer N, Martin R, McFarland HF, Quigley L, Cannella B, Raine CS, Scott DE, Loschmann PA, Racke MK (1997): Therapeutic potential of phosphodiesterase type 4 inhibition in chronic autoimmune demyelinating disease. J Neuroimmunol 79:54-61

Sternberg EM (2001): Neuroendocrine regulation of autoimmune/inflammatory disease. J Endocrinol 169:429-435

Swain MG, Appleyard C, Wallace J, Wong H, Le T (1999): Endogenous glucocorticoids released during acute toxic liver injury enhance hepatic IL-10 synthesis and release. Am J Physiol 276:G199-205

Wachtel H, Schneider HH (1986): Rolipram, a novel antidepressant drug, reverses the hypothermia and hypokinesia of monoamine-depleted mice by an action beyond postsynaptic monoamine receptors. Neuropharmacology 25:1119-1126

Yamamoto M, Sobue G, Li M, Arakawa Y, Mitsuma T, Kimata K (1993): Nerve growth factor (NGF), brain-derived neurotrophic factor (BDNF) and low-affinity nerve growth factor receptor (LNGFR) mRNA levels in cultured rat Schwann cells; differential time- and dose-dependent regulation by cAMP. Neurosci Lett 152:37-40

Yang YH, Hutchinson P, Santos LL, Morand EF (1998): Glucocorticoid inhibition of adjuvant arthritis synovial macrophage nitric oxide production: role of lipocortin 1. Clin Exp Immunol 111:117-122

Zhu J, Mix E, Winblad B (2001): The antidepressant and antiinflammatory effects of rolipram in the central nervous system. CNS Drug Rev 7:387-398 